\title{
EKONOMIA POLITYCZNA RELACJI MIĘDZYNARODOWYCH KORPORACJI WYDOBYWCZYCH Z PAŃSTWEM AFRYKAŃSKIM. PRZYPADEK TANZANII*
}

\author{
POLITICAL ECONOMY OF RELATIONS BETWEEN \\ INTERNATIONAL EXTRACTIVE CORPORATIONS \\ AND AFRICAN STATE: THE CASE STUDY OF TANZANIA
}

Andrzej Polus**, Wojciech Tycholiz***

\begin{abstract}
ABSTRAKT
Celem artykułu jest zaprezentowanie zarysu relacji pomiędzy rządem Tanzanii a działającymi tam korporacjami wydobywczymi, w szczególności w sektorze gazu naturalnego. Ramy teoretyczne artykułu osadzone są w krytycznej międzynarodowej ekonomii politycznej i sprowadzają się do współkonstrukcji uwarunkowań gospodarczych i politycznych w procesach negocjacyjnych, przy jednoczesnej akceptacji tezy, iż Tanzania jest obszarem peryferyjnym w międzynarodowym podziale pracy, a koncerny wydobywcze nie mają na celu zmiany jej pozycji. Po zaprezentowaniu charakterystyki tanzańskich złóż gazu omówione zostały wybrane elementy tanzańskiego reżimu politycznego, które zdaniem autorów
\end{abstract}

The article's primary aim is to present relations between Tanzanian government and foreign corporations active in extractive industries. The main theoretical framework used during the research process was constituted by the core assumptions of critical international political economy (CIPE). According to the CIPE, the political and economic spheres are mutually constructive, and Tanzania occupies peripheral position in international division of labour and multinational corporations do desire to bring any changes to this very situation. The article starts with brief presentation of Tanzania's potential in terms of the natural gas production and subsequently the core elements of Tanzanian political

* Artykuł jest wynikiem realizacji projektu badawczego Weryfikacja hipotezy klątwy surowcowej w Afryce Subsaharyjskiej. Przypadek Tanzanii, finansowanego przez Narodowe Centrum Nauki w ramach umowy - UMO-2015/17/B/HS5/00473.

** Uniwersytet Wrocławski, Wydział Nauk Społecznych. ORCID: https://orcid.org/0000-0002-6305-1599.

*** Uniwersytet Wrocławski, Wydział Nauk Społecznych.

ORCID: https://orcid.org/0000-0002-9494-8497. 
mają kluczowe znaczenie dla zrozumienia wagi górnictwa gazowego dla administracji prezydenta Magufuliego. Następnie omówione zostały czynniki warunkujące procesy negocjacyjne pomiędzy rządem tanzańskim a koncernami wydobywczymi.

Słowa kluczowe: Tanzania, gaz, państwo neopatrymonialne, surowce naturalne, przemysł wydobywczy regime which influence the relations between the government and multinational corporations were presented. Then, the core factors that shape the negation processes and negotiation positions of both sides were listed.

Keywords: Tanzania, natural gas, neopatrimonial state, natural resources, extractive industry

\section{WPROWADZENIE}

Tanzania jest jednym $\mathrm{z}$ niewielu państw subsaharyjskich, które oficjalnie wprowadzało w życie - skrajne w swoich założeniach - modele rozwoju społeczno-gospodarczego. U zarania niepodległości państwo to miało być samowystarczalne. Julius Nyerere wprowadzał w życie wizję socjalizmu afrykańskiego - ujamaa - inspirowanego doświadczeniami chińskimi i izraelskimi kibucami zaadoptowanymi do subsaharyjskich uwarunkowań (Coulson, 2013, s. 280-309), zaś po załamaniu gospodarczym w pierwszej połowie lat 80. ubiegłego wieku w Tanzanii wdrażano strukturalne programy dostosowawcze pod auspicjami Międzynarodowych Instytucji Finansowych. Zarówno w pierwszym, jak i w drugim przypadku rządy Tanzanii były zdeterminowane, aby wprowadzać określone rozwiązania w życie, jednakże w praktyce żadna $\mathrm{z}$ obranych dróg rozwojowych nie przyczyniła się do znaczącej poprawy poziomu życia Tanzańczyków.

Obecnie Tanzania jest jednym z najszybciej rozwijających się państw na kontynencie afrykańskim, lecz równocześnie plasuje się na ostatnich pozycjach w rankingach rozwoju społecznego. Powszechnie uznawana jest za państwo demokratyczne, w którym (za wyjątkiem Zanzibaru) wybory nie łączą się z eskalacją przemocy. Natomiast ukierunkowana na akumulację kapitału wewnątrz Tanzanii wizja rozwoju firmowana przez obecnego prezydenta Johna Magufuliego prezentowana bywa przez neoliberalne środki przekazu jako próba (skazana na niepowodzenie, sic!) ponownego wprowadzania socjalizmu afrykańskiego w tym państwie (The Economist, 19.10.2017).

Wraz z odkryciami bogatych złóż węglowodorów w Afryce Wschodniej po 2010 roku, w literaturze przedmiotu funkcjonuje narracja, według której dochody z górnictwa gazu, jeśli są dobrze zarządzane, będą przyczyniać się do rozwoju państwa, co znajduje również odzwierciedlenie w dokumentach pla- 
nistycznych tanzańskiego rządu (Ministry of Minerals, 2013). Autorzy tekstu postanowili poddać krytycznej analizie kluczową dla przyszłości tanzańskiego sektora gazowego kwestię dynamiki relacji rządu Tanzanii z korporacjami działającymi na rynku wydobycia gazu i wymienić czynniki, które odgrywają kluczowe znacznie w procesie negocjacyjnym. Pytanie o ekonomię polityczną wyżej wymienionej relacji jest ważne, gdyż produkcja kopalin w Afryce Subsaharyjskiej najczęściej prezentowana jest $\mathrm{w}$ dyskursie akademickim przez pryzmat klątwy surowcowej - twierdzenia, według którego istnieje negatywna korelacja pomiędzy występowaniem $\mathrm{w}$ danym państwie określonych kopalin a jego rozwojem polityczno-gospodarczym (Auty, 2002; Czernichowski, Kopiński, Polus, 2012). Wydaje się jednak, że koncepcja ta nie jest odpowiednia dla Tanzanii, gdyż produkcja gazu na szeroką skalę jeszcze się tam nie rozpoczęła, zaś państwo to jest w momencie tworzenia infrastruktury prawno-instytucjonalnej, która ma zapobiec wystąpieniu w przyszłości zjawiska klątwy surowcowej.

Warto w tym miejscu zaznaczyć, że Tanzania jest czwartym największym producentem złota w Afryce. Jednakże wpływy do budżetu państwa z tytułu danin i podatków od korporacji wydobywających ten surowiec praktycznie nie miały miejsca. Podobnie wygląda sytuacja w kontekście tanzanitu (kamienia szlachetnego występującego wyłącznie w Tanzanii wokół Arushy i Moshi). Jednocześnie w trakcie badań terenowych pytania o możliwość wystąpienia w tym państwie zjawiska klątwy surowcowej wielokrotnie budziły niechęć tanzańskich elit politycznych. Złe zarządzanie sektorem produkcji złota jest tematem delikatnym; dość wspomnieć, że wysoki rangą urzędnik Narodowego Banku Tanzanii w trakcie wywiadu odmówił udzielania jakichkolwiek informacji ze względu na zawarte w opisie projektu zestawienie zjawiska klątwy surowcowej z Tanzanią. Równocześnie należy przyznać, że pomimo braku ostatecznej decyzji dotyczącej budowy terminala LNG w Tanzanii przyjęte zostały najważniejsze ustawy regulujące wydobycie tego surowca, co jest sytuacją wyjątkową w Afryce Subsaharyjskiej, gdzie zazwyczaj w państwach surowcowych prawo tworzone było równolegle $\mathrm{z}$ ich (surowców) wydobyciem lub nawet dopiero po rozpoczęciu wydobycia. $Z$ drugiej strony liczne kontrowersje budził tryb procedowania i przyjmowania ustaw regulujących wydobywanie gazu (proces legislacyjny odbył się bardzo szybko i niemalże bez partycypacji ugrupowań opozycyjnych i konsultacji społecznych) - fakt ten stanowi dodatkową racjonalizację dla podjęcia przez autorów tematu relacji rządu z korporacjami wydobywczymi.

Dalsza część artykułu podzielona została na cztery części. W części pierwszej syntetycznie opisana została charakterystyka tanzańskich złóż gazu i aktorów 
biorących udział w negocjacjach. W części drugiej omówiony został reżim polityczny Tanzanii wraz z uwarunkowaniami politycznymi negocjacji pomiędzy rządem a korporacjami wydobywczymi. Część trzecia artykułu poświęcona została strategiom negocjacyjnym i zasobom, które posiadają korporacje międzynarodowe $\mathrm{w}$ relacjach $\mathrm{z}$ tanzańskim rządem. W ostatniej części tekstu zamieszczone zostało podsumowanie wraz z konkluzjami.

Badania prowadzone były w ramach fundamentalnych założeń krytycznej międzynarodowej ekonomii politycznej, według których system polityczny i system gospodarczy współkształtują się wzajemnie, zaś w środowisku międzynarodowym istnieją instytucje i wzorce dominacji, które wprawdzie ulegają zmianie, ale tworzone były i są dla utrzymania wzorców dominacji i eksploatacji jednych aktorów przez innych. Wśród głównych technik badawczych użytych dla opisu i omówienia relacji międzynarodowych korporacji wydobywających surowce i rządu tanzańskiego wymienić należy: analizę materiału zastanego, ponad 30 częściowo ustrukturyzowanych wywiadów pogłębionych przeprowadzonych podczas badań terenowych w Tanzanii (wrzesień--październik 2016), obserwację oraz analizę statystyczną i analizę (makro)ekonomiczną.

\section{GAZ JAKO NOWY CZYNNIK W TANZAŃSKIEJ POLITYCE}

Pierwsze odkrycia złóż gazu ziemnego w ilościach komercyjnych w Tanzanii nastąpiły w latach 70. ubiegłego wieku. Gaz ziemny został wtedy odkryty podczas poszukiwań ropy naftowej (Friedrich-Ebert-Stiftung, 2015, s. 12-14; s. 19-62). W konsekwencji kolejnych odkryć potwierdzone złoża tego surowca szacowane były w 2017 roku na 6,5 miliarda metrów sześciennych (CIA, 2017), co $\mathrm{w}$ porównaniu $\mathrm{z}$ innymi państwami gazowymi na świecie stawia Tanzanię dopiero na 90 miejscu pod względem wielkości złóż. Jednakże istnieją duże szanse, iż potwierdzone zostaną kolejne pokłady gazu o charakterze komercyjnym. Niemalże cały tanzański gaz ulokowany jest pod dnem Oceanu Indyjskiego (tzw. złoża typu offshore), co z jednej strony sprawia, że ich eksploatacja nie wiąże się z koniecznością przesiedleń lokalnej ludności i nie rodzi problemów związanych $\mathrm{z}$ tytułami własności ziemi, z drugiej jednak podraża koszty wydobycia i transportu. Obecnie surowiec ten wydobywany jest z dwóch złóż: SongoSongo oraz Mnazi Bay i używany głównie do produkcji energii elektrycznej na rynek tanzański. Niemniej jednak, biorąc pod uwagę ogromne zapotrzebowanie Tanzanii na energię elektryczną, której produkcja w hydroelektrowniach bywa 
nieefektywna z uwagi na (co raz częściej) występujące w kraju susze, gaz prezentowany jest w debacie publicznej jako czynnik, który. ustabilizuje dostawy energii elektrycznej, zwiększy przychody do budżetu federalnego, przyczyni się do przyspieszonej industrializacji kraju i w konsekwencji do osiągnięcia przez Tanzanię statusu państwa o średnim dochodzie w ciągu najbliższej dekady.

W celu realizacji ogłoszonym przez tanzański rząd planów rozwojowych konieczne jest zbudowanie terminala LNG, który umożliwiłby skroplenie i eksport tanzańskiego gazu na rynki międzynarodowe (głównie pod uwagę brane są rynki azjatyckie). Według dostępnych szacunków ewentualny eksport gazu przyniósłby Tanzanii dodatkowe wpływy budżetowe na poziomie od 2,3 (Scurfield, Mihalyi, 2017) do 3 mld USD rocznie (Pedersen, Bofin, 2015, 5). Zważywszy, że w roku budżetowym 2017/18 przychody zaplanowane zostały na poziomie $16,5 \mathrm{mld}$, dodatkowe wpływy ze sprzedaży surowca stanowiłyby przeszło $15 \%$ budżetu państwa.

Głównymi korporacjami wydobywczymi prowadzącymi działalność w Tanzanii są: Statoil, Exxon Mobil, Ophir oraz Shell. Natomiast w już w 1969 roku tanzański rząd utworzył Tanzania Petroleum Development Corporation (TPDC) - dedykowany podmiot reprezentujący interes Tanzanii w sektorze. W pierwszych latach działalności mandat TPDC ograniczał się do nadzorowania aktywności korporacji międzynarodowych (Kassum, 2007, s. 126). W kolejnych latach zakres działalności TPDC został rozszerzony o produkcję, transport, rafinowanie, dystrybucję i sprzedaż węglowodorów (Economic and Social Research Foundation, 2009, s. 63). TPDC reprezentuje także interesy Tanzanii w kontaktach $\mathrm{z}$ korporacjami międzynarodowymi - negocjuje warunki umów licencyjnych, tworzy spółki joint-venture oraz partycypuje w inwestycjach. Z kolei w gestii Ministerstwa Kopalni i Energii (ang. Ministry of Mines and Energy) jest wytyczanie kierunków rozwoju sektora surowcowego, tworzenie regulacji prawnych oraz nadzór nad sektorem surowcowym (w tym nad procesem negocjacji umów gazowych).

Jak do tej pory największe zaangażowanie finansowe w Tanzanii wykazał norweski Statoil, który w latach 2010-2014 zainwestował blisko 6 miliardów NOK (około 730 mln USD) (Stadtoil, https:/www.statoil.com/en/where-we-are/ tanzania.html). W Tanzanii funkcjonuje powiedzenie - „jeśli wahasz się, kto $\mathrm{z}$ dwóch liderów ma wyższą pozycję w danej społeczności - spójrz na ich domostwa" (Wywiad z Exuperius Tax, Project Manager, SandRose, Dar es Salaam, 27.09.2016). Siedziba Statoil w Dar es Salam jest samodzielnym, szklanym i najwyższym budynkiem w najbardziej ekskluzywnej dzielnicy miasta, podczas 
gdy inne korporacje wynajmują powierzchnie (często całe piętra) w biurowcach. Statoil posiada również najwięcej udziałów w blokach wydobywczych, w których obecnie prowadzona jest eksploracja gazu.

Zaskakującym elementem badań terenowych w Tanzanii była niezwykła otwartość korporacji wydobywczych i wola rozmowy z autorami artykułu. Sytuacja ta jest naprawdę wyjątkowa, gdyż dostęp do korporacji wydobywczych był zawsze największym problemem podczas prowadzenia badań terowych w Afryce. Niemniej należy w tym miejscu zaznaczyć, że ani jedna stopa sześcienna tanzańskiego gazu nie została jeszcze sprzedana na rynkach międzynarodowych i „otwartość” koncernów wydobywających gaz może ulec zmianie po rozpoczęciu produkcji. Według relacji rzeczników prasowych wszystkich korporacji wydobywczych obecnych w Tanzanii są one zmuszone czekać na ruch ze strony rządowej, która ,jest niezwykle „ostrożna w podejmowaniu jakichkolwiek decyzji” (wywiady z rzecznikami prasowymi korporacji wydobywczych aktywnych w Tanzanii). Jednocześnie korporacje wydobywcze cały czas nie ogłosiły jeszcze ostatecznej decyzji inwestycyjnej (ang. final investment decision) dotyczącej budowy terminala LNG w Tanzanii, którego koszt szacowany jest na około 30 miliardów USD. W chwili obecnej to właśnie od podjęcia tej decyzji uzależnione jest powodzenie przekształcenia Tanzanii w państwo eksportujące gaz.

\section{REŻIM POLITYCZNY TANZANII, "EFEKT MAGUFULIEGO” I ZMIANY W TANZAŃSKIM PRAWIE W OBRĘBIE PRODUKCJI SUROWCÓW NATURALNYCH}

Tanzania należy do najstabilniejszych politycznie państw w Afryce Subsaharyjskiej. Od uzyskania przez Tanganikę niepodległości od Wielkiej Brytanii w 1962 roku scena polityczna tego państwa (najpierw Tanganiki, a następnie, po wejściu w życie unii z Zanzibarem, Tanzanii) zdominowana jest przez jedną partię polityczną Chama Cha Mapinduzi (suahili: Partia Rewolucji), CCM¹. CCM jest obecnie najdłużej pozostającym nieprzerwanie u władzy ugrupowaniem politycznym w Afryce Subsaharyjskiej. Historia Tanzanii wiąże się nierozerwanie z osobą

1 CCM powstał w wyniku zjednoczenia w 1977 roku rządzącej w Tanganice partii TANU (Tanganyika African National Union) i ASP (Afro-Shirazi Party) z Zanzibaru. Na czele TANU a potem CCM stał Julius Nyerere. 
Juliusa Nyerere ${ }^{2}$, który stał na czele państwa do 1985 roku, zaś po jego wycofaniu się z czynnego życia politycznego każdy z jego następców sprawował urząd przez dekadę, odnawiając mandat w wyborach po pięciu latach prezydenckich rządów. Zasada pozostawania prezydenta na urzędzie przez 10 lat jest nieformalną cechą tanzańskiego reżimu politycznego i z dużym prawdopodobieństwem można przewidywać, że obecny prezydent - John Pumba Magufuli (określany w Tanzanii akronimem JPM oraz noszący przydomek „buldożer”) będzie rządził tym państwem do 2025 roku $^{3}$. Tym samym międzynarodowe koncerny działające w obszarze wydobycia węglowodorów wiedzą, że prawdopodobnie cała faza tworzenia infrastruktury regulującej górnictwo gazu oraz budowa (jeśli do niej dojdzie, s) terminala LNG będzie odbywała się przy współpracy z jedną ekipą rządową.

Pluralizm polityczny został wprowadzony w Tanzanii w 1992 roku (pod naciskiem międzynarodowych instytucji finansowych), wcześniej (od roku 1977) jakakolwiek działalność polityczna poza CCM była penalizowana. Niemniej jednak, pomimo że formalnie mamy tam do czynienia z pluralizmem politycznym, tanzańskie ugrupowania opozycyjnie nie zdołały w przeciągu ostatniego ćwierćwiecza odegrać znaczącej roli na scenie politycznej tego państwa. Sytuacja ta jest wynikiem splotu kilku czynników. Po pierwsze dekady pozostawania CCM u władzy pozwoliły temu ugrupowaniu na gromadzenie środków i zbudowanie infrastruktury partyjnej w całym kraju, co bardzo trudnym czyni dla opozycji współzawodnictwo z partią rządzącą. Sytuacja ta jest szczególnie widoczna na terenach wiejskich, zaś bastionami opozycji są tanzańskie miasta. Po drugie jedność państwa, które jest niezwykle heterogeniczne pod względem etnicznym i religijnym, pozostaje imperatywem w polityce wewnętrznej. Pomimo istnienia widocznego i wieloaspektowego podziału na północ i południe kraju (opozycja jest znacznie silniejsza na północy), nie powstały ugrupowania partyjne, które próbowałyby organizować się na bazie regionalnej, etnicznej czy religijnej. Po trzecie w końcu Tanzania uznana być może za klasyczny przykład państwa neopatrymonialnego, w którym poszczególne frakcje CCM - w zamian za lojalność wobec patronów - utrzymywały określone stanowiska państwowe.

2 Kluczowym wydarzeniem w drugiej połowie lat 60. ubiegłego wieku w polityce wewnętrznej Tanzanii było przyjęcie „Deklaracji z Aruszy”, która zdefiniowała politykę państwa tanzańskiego jako walkę o charakterze moralnym z wyzyskiem wewnątrzpaństwowym i międzynarodowym.

$3 \mathrm{~W}$ trakcie wywiadów z tanzańskimi politykami opozycyjnymi pojawiało się stwierdzenie, że CCM rozważa zmianę konstytucji i wydłużenie kadencji prezydenckich do 7 lat, co pozwoliłoby JPM rządzić Tanzanią do 2029 roku. 
O ile tanzańska klasa polityczna jest relatywnie mała, to równocześnie jest ona zdywersyfikowana, jeśli chodzi o jej pochodzenie (miasta, wsie), religię (chrześcijaństwo, islam) oraz przynależność etniczną. Niemniej cechą wspólną tanzańskiej elity politycznej jest rozumienie polityki wewnętrznej jako jednej z dróg do wzbogacania się (Wywiad z dr. Bruce Heilman, Department of Political Science and Public Administration, University of Dar es Salaam, Dar es Salaam 19.09.2016). Według tanzańskich intelektualistów, z którymi dane było rozmawiać autorom artykułu, owa percepcja polityki jako sposobu na wzbogacenie się ma swoje początki w końcowym okresie rządów Juliusia Nyerere, kiedy Tanzania znalazła się w głębokim kryzysie gospodarczym (Wywiad z Victor P. Kimesera, National Executive Secretary CHADEMA, Siedziba CHADEMA, Dar es Salaam 26.09.2016). Jednakże obecny prezydent szedł do wyborów z hasłem wyrugowania niegospodarności i korupcji z życia politycznego Tanzanii ${ }^{4}$. Co ciekawe, na czele opozycji stanął wówczas były premier, który był postrzegany jako osoba, która (pomimo ciągłego oskarżania CCM o korupcję), jeśli pokona Magufuliego, może w przyszłości prowadzić politykę opierającą się na nie do końca jasnych związkach biznesu z rządem. Należy w tym miejscu zaznaczyć, że tanzańskie partie polityczne nie mają jasno określonej linii ideologicznej. CCM odeszło w okresie wdrażania strukturalnych programów dostosowawczych od haseł socjalizmu afrykańskiego, zaś opozycyjna CHADEMA powstała jako partia klasy średniej, by następnie przejąć część haseł Juliusa Nyerere i powoływać się na jego dziedzictwo. Ponadto, zarówno opozycja, jak i partia rządząca nie są monolitami, a funkcjonujące w ich ramach frakcje często mają sprzeczne interesy. Sposobem na utrzymanie jedności partyjnej - w szczególności w przypadku partii rządzącej - było (i nadal jest) proporcjonalne dzielenie dostępu do stanowisk i środków publicznych..

Na przełomie lat 2016/17 prezydent Magufuli wypowiedział bezprecedensową w historii Tanzanii wojnę niegospodarności i korupcji w rządzie, naruszając tym samym status quo pomiędzy różnymi grupami interesu. Jednakże na dłuższą

4 Wśród najgłośniejszych decyzji nowego prezydenta, które mają zmniejszyć deficyt budżetowy znalazły się m.in. odwoływanie parad z okazji dnia niepodległości, zakaz lotów pierwszą klasą dla członków administracji państwowej, zakaz organizowania spotkań poza biurem, czy nawet zakaz wysyłania kartek świątecznych przez urzędników państwowych na koszt podatników. Jakkolwiek zabawnie to brzmi, absolutnie wszyscy taksówkarze w Dar es Salaam oraz osoby prowadzące restaurację zwracały uwagę podczas rozmów $\mathrm{z}$ autorami tekstu, że ich obroty pod rządami JPM spadły o kilkadziesiąt procent, gdyż urzędnicy państwowi, którzy dotychczas stanowili ich klientelę, nie są już tak chętni do wydawania pieniędzy jak podczas prezydentury Jakayi Kikwete. 
metę prezydent nie może rządzić Tanzanią „ręcznie” - na wzór Paula Kagame w Rwandzie, gdyż rozmiar Tanzanii nie pozwala na efektywne sprawowanie rządów jednoosobowych. Co ciekawe, bezpośrednie zarządzanie państwem przez prezydenta można również zaobserwować w sąsiedniej Ugandzie, której przykład dobrze obrazuje, iż to, co działa w Ruandzie, jest trudno przeszczepialne do większych organizmów państwowych i efektywne wdrażanie programów rozwojowych wymaga klasy profesjonalnych urzędników służby cywilnej. Równocześnie zarówno w Ugandzie, jak i Rwandzie istnieje przyzwolenie społeczne na funkcjonowanie silnego i scentralizowanego ośrodka władzy ze względu na konflikty wewnętrzne i chęć ich uniknięcia w przyszłości. Tanzania natomiast nie jest społeczeństwem pokonfliktowym. Innymi słowy, prezydent musi mieć tam oparcie w większości członków CCM, gdyż inaczej istnieje groźba odsunięcia go od władzy po pierwszej kadencji (a w zasadzie niedopuszczenie do jego kandydowania w wyborach - to partie polityczne desygnują kandydatów). Nie oznacza to jednak, że Magufuli nie poszedł na kompromis ze swoim poprzednikiem Jakayą Kikwete, który doskonale lawirował pomiędzy różnymi frakcjami wewnątrz partii. Obejmując urząd, Magufuli publicznie obiecał mu, iż „, bierze go pod swoją ochronę" i nie pozwoli, aby wszczynane były przeciwko niemu jakiekolwiek postępowania w związku z domniemanymi skandalami korupcyjnymi. Sytuacja ta piętnowana jest przez opozycję i prezentowana jako przejawy słabości JPM i uzależnienia od Kikwete, który po odejściu z urzędu prezydenta stał cały czas na czele partii i przez dłuższy czas nie przekazał tego stanowiska nowemu szefowi państwa. Tym samym władza obecnego prezydenta nie opiera się nie tyle na rozdawaniu stanowisk, ile na możliwości niewszczynania postępowań karnych wobec osób, co do których istnieją podejrzenia korupcyjne. Ponadto JPM został powołany na ministra infrastruktury właśnie przez Jakayę Kikwete, tym samym krytyka poprzedniej administracji byłaby w jakimś stopniu również krytyką jego własnych działań, gdyż obecny prezydent był członkiem poprzedniego rządu.

$\mathrm{W}$ trakcie badań terenowych sytuacja polityczna w Tanzanii przedstawiana była najczęściej w ramach narracji, którą określić można jako „poczekamy, zobaczymy”; „jest zbyt wcześnie, żeby wydawać sądy o nowym prezydencie” (ang. wait and see, it's too early to judge), pomimo że prezydent pozostaje u władzy ponad dwa lata, istnieje przekonanie, że nie doszło jeszcze do próby sił pomiędzy nim a zwolennikami/beneficjentami starego porządku5 . Większość responden-

5 Autorzy są wdzięczni uczestnikom NYASA Annual Conference w Buffalo na zwrócenie uwagi na wagę tej narracji dla obecnej sytuacji polityczno-gospodarczej Tanzanii. 
tów nie ukrywała, że w partii rządzącej istnieją siły przeciwne prezydentowi, nikt jednak nie wie (bądź autorom nie udało się uzyskać takiej informacji), jak liczna jest opozycja wobec głowy państwa, gdyż oficjalnie CCM stanowi jedność i wszyscy jej członkowie udzielają bezwarunkowego poparcia JPM.

Obecna sytuacja polityczna czyni relację pomiędzy korporacjami zajmującymi się wydobyciem i sprzedażą gazu a rządem Tanzanii bardziej skomplikowaną niż pod rządami Jakayi Kikwete. Jak wzmiankowano wcześniej, reprezentanci wszystkich korporacji z którymi dane było rozmawiać autorom podkreślali, że nową administrację cechuje „niezwykła ostrożność” w podejmowaniu jakichkolwiek decyzji dotyczących sektora gazowego. Ostrożność ta wynika głównie z daleko posuniętej centralizacji procesów decyzyjnych w Tanzanii. Prezydent posiada wąskie grono zaufanych ludzi, którzy nie są w stanie szybko odpowiadać na zapotrzebowanie korporacji wydobywczych w zakresie podejmowania decyzji administracyjnych i informowania o stanowisku rządu wobec wybranych kwestii. Reprezentanci sektora gazowego niemal jednogłośnie zwracali uwagę, że nawet najprostsze - ich zdaniem - uzgodnienia, które nie narażają budżetu państwa na jakiekolwiek wydatki rozciągają się niezwykle w czasie. Po drugie, obecna administracja znajduje się pod ogromną presją demograficzną i wiążącym się z tym problemem bezrobocia wśród ludzi młodych. Co roku na tanzański rynek pracy wchodzi około 800000 osób, zaś poprzednie administracje w ogóle nie zarządzały oczekiwaniami społecznymi związanymi z górnictwem gazu, co spowodowało, że wiele osób postrzega je jako sposób na dalsze wzbogacanie się elity politycznej w Dar es Salaam. Narracja ta wzmacniana jest przez fakt, że już wydobywany gaz transportowany jest do Dar es Salaam i tam przetwarzany na energię elektryczną. Tym samym, według rządu, konieczne jest wytworzenie takiego systemu, który nie tylko sprawi, że podatki będą ściągane przez państwo tanzańskie od korporacji wydobywczych, ale przede wszystkim, że tanzańscy przedsiębiorcy będą mogli dostarczać usługi i towary podczas tworzenia infrastruktury związanej z wydobywaniem i transportem tego surowca.

Konkludując dotychczasową część wywodu, zauważyć należy, że o ile zwycięstwo CCM w wyborach z 2015 roku nie było wielkim zaskoczeniem, to determinacja JPM w walce $\mathrm{z}$ korupcją i samodzielne sterowanie krajem zmuszają korporacje wydobywcze do zmiany strategii negocjacyjnych i uwzględnienia jeszcze dłuższego niż do tej pory czasu oczekiwań na odpowiedź administracji rządowej oraz implementację poszczególnych decyzji. Rząd natomiast wydaje się być świadomy, że w przeszłości Tanzania nie potrafiła zmusić korporacji wydobywających złoto do płacenia podatków, dlatego stara się przede wszyst- 
kim wprowadzić regulacje, które promować będą lokalną wartość dodaną, na przykład poprzez nabywanie dóbr i usług od lokalnych przedsiębiorców oraz zatrudnianie Tanzańczyków na wszystkich szczeblach (tzw. localcontent law). Z kolei rosnąca presja budżetowa zwiększa determinację rządu do stworzenia efektywnego prawa podatkowego i traktowania Tanzanii przez korporacje jako „równych partnerów”.

W czerwcu 2017 roku tanzański parlament uchwalił trzy nowe - zdaniem niektórych rewolucyjne - ustawy zmieniające ramy prawne funkcjonowania sektora surowców naturalnych. Pierwsza ustawa wprowadza różne poprawki do już istniejących aktów prawnych (m.in. w prawie podatkowym). Druga wprowadza zasady zwierzchności rządu Tanzanii nad bogactwami naturalnymi kraju i czerpania $\mathrm{z}$ nich pożytków. Natomiast trzecia z ustaw zawiera zbiór przepisów umożliwiających rządowi renegocjacje istniejących umów z korporacjami wydobywczymi ${ }^{6}$.

Przedstawiciele wielu działających w Tanzanii korporacji wydobywczych wprowadzone zmiany uważają za „krok w tył” i ogłosili „rewizję polityki inwestycyjnej" w kraju (The East African, 2017). Najbardziej krytyczną postawę wobec wprowadzonych zmian wyraziła Acacia Mining - największy producent złota w Tanzanii. Nie bez znaczenia jest tutaj zapewne fakt, że tanzański rząd oskarżył Acacia Mining o zaniżanie ilości wydobytego złota, przychodów i należnych podatków „przez wiele kolejnych lat o dziesiątki miliardów dolarów” (Aglionby, 2017). Łączna wartość nałożonych na Acacia Mining kar, zaległych podatków i odsetek wyniosła 190 miliardów USD (The Citizen, 2017), tj. 4,5-krotność tanzańskiego PKB za 2015 rok.

Część nowych regulacji ma charakter porządkowy, reorganizacyjny i zwiększający rolę urzędu prezydenta w zarządzaniu sektorem. Przykładowo, w świetle nowego prawa, dysponentem surowców naturalnych w Tanzanii jest Prezydent (wcześniej surowce powierzone były Zjednoczonej Republice Tanzanii i Zanzibaru). Podobnie wcześniej za przyznawanie licencji wydobywczych odpowiedzialny był minister właściwy ds. górnictwa - obecnie zadanie to powierzone zostało rządowi (The Parliament of Tanzania. 2017a).

6 Pełne nazwy przyjętych ustaw to: (1) the Written Laws (Miscellaneous Amendments) Act 2017 („Amendments Act”), (2) the Natural Wealth and Resources (Permanent Sovereignty) Act 2017 („Sovereignty Act”) and (3) the Natural Wealth and Resources (Revenue and Re-Negotiation of Unconscionable Terms) Act 2017 (“Contract Review Act”). 
Kolejna grupa przepisów zmienia prawo podatkowe, zwiększając m.in. opłaty koncesyjne na złoto i kamienie szlachetne z 5 na $6 \%$, a na metale z 4 do 5\% (The Parliament of Tanzania, 2017c, Section 23). Najistotniejszą zmianą w reżimie fiskalnym jest zmiana sposobu wyznaczania wartości bazowej (podstawy opodatkowania) surowców. Wcześniej wartość ta ustalana była na podstawie „wartości rynkowej minerałów w miejscu rafinowania (...) lub miejscu dostawy w Tanzanii”. Takie sformułowanie przepisów dawało korporacjom wydobywczym pole do zaniżania wartości rynkowej (np. stosując korekty wartości rynkowej w związku z wysoką negatywną zmiennością cen danego surowca). W efekcie dostosowywania cen przez korporacje płacone przez nie podatki były absurdalnie niskie.

Dodatkowo nowe przepisy mają zmniejszyć (przynajmniej częściowo) straty podatkowe wynikające ze stosowania cen transferowych. Powszechną praktyką stosowaną przez korporacje jest „przesuwanie” podatków z jednego podmiotu na inne spółki zależne. W myśl nowych przepisów, wynikająca z takiego działania korzyść podatkowa obłożona została dodatkowym podatkiem w wysokości... 100\% (The Parliament of Tanzania, 2017c: Section 33 oraz Section 37).

Nowe przepisy podatkowe zmieniają także procedurę ustalania wartości rynkowej surowców. Zgodnie z ich zmienioną treścią wartość rynkowa surowców ustalana ma być na podstawie wyceny dokonywanej przy obecności lokalnego komisarza ds. górnictwa oraz przedstawiciela Tanzańskiego Urzędu Podatkowego. Co więcej nowe prawo wprowadza możliwość odrzucenia przez władze wyceny eksportowanych surowców, jeżeli ta uznana zostanie za zaniżoną, i jednocześnie przyznaje rządowi w takim przypadku opcję do ich pierwokupu (po zaniżonej cenie). Istotne zmiany podatkowe wprowadzono także w prawie podatkowym korporacji wydobywających gaz. W myśl nowych przepisów status kosztu podatkowego straciły opłaty koncesyjne, a tym samym zwiększona została podstawa opodatkowania (The Parliament of Tanzania, 2017c: Section 36).

Nowe prawo podnosi także wielkość udziałów przypadających rządowi tanzańskiemu we wszystkich przedsięwzięciach związanych z wydobyciem surowców w Tanzanii z 8 do 16\% (np. w spółkach joint-venture tworzonych $\mathrm{z}$ korporacjami międzynarodowymi), a w niektórych przypadkach nawet do $66 \%$, zaś ulgi podatkowe przyznawane poszczególnym podmiotom w związku $\mathrm{z}$ ich planowanymi inwestycjami w sektorze surowcowym mogą być konwertowane przez rząd na akcje tych podmiotów (The Parliament of Tanzania, 2017c: Section 25). Regulacje te na pewno wpłyną istotnie na kształt negocjowanej 
właśnie umowy ramowej pomiędzy tanzańskim rządem a konsorcjum korporacji planujących budowę terminala LNG - wielkość związanych z tą inwestycją ulg podatkowych liczona będzie w setkach milionów dolarów.

Kolejnym elementem zmieniającym uwarunkowania negocjacji jest nałożony przez nowe prawo obowiązek umożliwienia mieszkańcom Tanzanii bezpośredniej partycypacji w zyskach z wydobycia surowców (np. poprzez możliwość zakupu akcji spółek wydobywczych na giełdzie w Dar es Salaam - w takim przypadku wszystkie korporacje działające w Tanzanii musiałyby wprowadzić swoje akcje do obrotu na lokalnej giełdzie).

Jedną z najważniejszych zmian wprowadzonych przez nowe prawo jest możliwość renegocjacji wszystkich obowiązujących obecnie kontraktów z korporacjami wydobywczymi. W myśl przepisów każda podpisana do tej pory umowa ma zostać poddana szczegółowemu audytowi i w razie gdyby jakikolwiek jej zapis uznany został za „niezgodny z sumieniem” (ang. unconsiousable) i sprzeczny $\mathrm{z}$ interesem narodowym, mogłaby ona zostać rozwiązania. Przykładowo występowanie w umowie zapisu o stosowaniu arbitrażu międzynarodowego (co było dość powszechną praktyką w podpisywanych umowach) stanowi wystarczającą podstawę do renegocjacji całej umowy (The Parliament of Tanzania. 2017b). W tym miejscu należy nadmienić, że nowe przepisy nakazują rozstrzyganie wszelkich sporów przez sądy tanzańskie (uniemożliwiając tym samym stosowanie klauzul o arbitrażu międzynarodowym).

Zmiany dotyczą także możliwości stosowania i zakresu klauzul stabilizacyjnych (ang. stabilistaion clauses). W myśl nowych przepisów wszelkie klauzule stabilizacyjne, po pierwsze, nie mogą „zamrażać prawa lub zabierać [Tanzanii] zwierzchności nad surowcami”; po drugie, klauzule te powinny być „specyficzne”, tj. odnosić się do wąskiego i precyzyjnego zakresu prawa; i po trzecie, ich obowiązywanie w czasie ma być ograniczone i podlegać cyklicznym renegocjacjom (co 5 lat) (The Parliament of Tanzania, 2017c: Section 25).

W zakresie wymagań dotyczących licencji na poszukiwanie i wydobycie surowców najważniejszym postanowieniem nowego prawa jest nałożenie na posiadacza licencji obowiązku wywiązania się z planu inwestycyjnego, bowiem odsprzedaż licencji możliwa będzie tylko w przypadku, gdy licencjodawca (tj. tanzański rząd) uzna, że podmiot odsprzedający licencje wywiązał się ze przedłożonych wcześniej planów inwestycyjnych (The Parliament of Tanzania, 2017c: Section 8). Założeniem nowych przepisów jest minimalizacja liczby czy też całkowite wykluczenie przypadków, w których podmioty nabywają licencję poszukiwawcze i/lub wydobywcze, trzymają je przez kilka lat, nie dokonując 
żadnych inwestycji, a następnie odsprzedają z zyskiem. Takie działanie, w świetle nowych przepisów, nie będzie już możliwe.

Kolejna rewolucyjna zmiana dotyczy możliwości eksportu nieprzetworzonych surowców. Sekcja 9. Sovereignty Act nakazuje bowiem, co do zasady, aby każdy wydobyty surowiec został wzbogacony w Tanzanii przed jego eksportem. Tym samym nowe przepisy wprowadzają zakaz wywozu z Tanzanii nieprzetworzonych surowców - przepisy te mają na celu przyspieszyć realizację założeń prezydenta Magufuliego dotyczących przyspieszonej industrializacji Tanzanii w najbliższych latach.

Wreszcie, w celu dalszego uszczelnienia systemu poboru opłat i podatków, każdy wydobyty surowiec, zanim zostanie poddany obróbce i wyeksportowany, musi trafić do Rządowego Magazynu Surowców, gdzie zostanie wyceniony przez komisję, w której skład wchodzić ma m.in. przedstawiciel urzędu podatkowego. Nie wiadomo natomiast - przepisy tego nie precyzują - czy do Rządowego Magazynu Surowców transportowany ma być również gaz. Wydaje się, że choćby z punktu widzenia praktycznego przepisy te nie będą miały zastosowania (przynajmniej wprost) do gazu naturalnego.

Uchwalone przez tanzański parlament prawo w wielu miejscach wprowadza regulacje rewolucyjne w skali kontynentu afrykańskiego. Proponowane rozwiązania, w tym częściowa konwersja przyznanych ulg podatkowych na akcje, zakaz odsprzedaży licencji bez zrealizowania zgłoszonego w trakcie nabycia licencji planu inwestycyjnego czy nakaz uszlachetniania i obróbki surowców przed ich eksportem, wydają się być zasadne i kompatybilne z celami rozwojowymi Tanzanii.

Jednak jak podkreślają eksperci, wiele $\mathrm{z}$ wprowadzonych przepisów jest niejednoznacznych i wymagać będzie doprecyzowania w aktach wykonawczych (Woodroffe, Genasci, Scurfield, 2016). Bez wątpienia jednak wprowadzone zmiany wzmacniają pozycję negocjacyjną prezydenta i rządu w konfrontacji $\mathrm{z}$ korporacjami międzynarodowymi, dostarczając im wielu nowych narzędzi $\mathrm{w}$ walce $\mathrm{z}$ cenami transferowymi, umożliwiając też nabywanie licencji w celach spekulacyjnych czy niewywiązywania się z obowiązków inwestycyjnych.

Kluczową dla przyszłości politycznej Tanzanii kwestią pozostaje pytanie, czy rządowi uda się zapewnić stały dopływ dodatkowych środków związanych z eksportem gazu przed zakończeniem drugiej kadencji JPM. Jeśli tak by się stało, to w każdym z dwóch - zarysowanych poniżej - najbardziej prawdopodobnych scenariuszy rozwój Tanzanii zapewniłoby pozostawanie u władzy CCM. W pierwszym scenariuszu prezydent Magufuli, reinwestuje środki z gazu 
wewnątrz państwa i wspomaga jego industrializację, co wzmacnia jego mandat. W drugim mamy powrót do reżimu neopatrymonialnego, zaś środki zdobyte od koncernów gazowych używane są dla utrzymania sieci patronażu wewnątrz Tanzanii.

\section{GŁÓWNE CZYNNIKI DETERMINUJĄCE POZYCJE NEGOCJACYJNE W SEKTORZE GAZOWYM}

Negocjacje pomiędzy korporacjami wydobywczymi a tanzańskim rządem toczyły się w trakcie prac nad artykułem i ich wynik jest wysoce niepewny. Niemniej jednak na podstawie zebranego materiału faktograficznego można nakreślić zarys stanowisk obu stron i wyłanianie się pól, na których pojawić się mogą kontrowersje.

Pierwszym czynnikiem, który strukturalizuje proces negocjacyjny, jest przyjęta przez administrację prezydenta Magufuliego strategia industrializacji Tanzanii. Gaz jest elementem koniecznym dla jej realizacji. Z jednej strony wzrost wydobycia sprawi, że możliwe będzie wykorzystanie tego surowca na szerszą skalę w procesie elektryfikacji państwa (przerwy w dostawach gazu i słaba infrastruktura są postrzegane jako główne przyczyny nierozwijania się przemysłu w Tanzanii); z drugiej środki uzyskane dzięki podatkom płaconym przez korporacje wydobywcze będą stanowiły kapitał inwestycyjny. Jeśli prezydent Magufuli ma zrealizować plan przekształcenia swojego państwa w kraj o średnim dochodzie podczas pozostających mu ośmiu lat rządów, musi wdrażać założone projekty w życie, a sektor gazowy wydaje się naturalnym źródłem kapitału.

Korporacje wydobywcze natomiast, angażując się w Tanzanii, działają w kontekście globalnym. Tanzania jest dla nich jednym z wielu aktywów. Aktywem obiecującym, ale możliwym do porzucenia, jeśli gdzieś indziej pojawią się lepsze perspektywy lub warunki umowy z tanzańskim rządem będą nie do zaakceptowania.

Kolejnym czynnikiem, który należy brać pod uwagę w procesie negocjacji, jest cena gazu. Inwestycje w górnictwo węglowodorów są ze swojej natury długoterminowe i wiążą się z dużą kapitałochłonnością, zaś relatywnie niskie obecnie ceny ropy i gazu na rynkach międzynarodowych wzmacniają pozycję negocjacyjną korporacji wydobywczych. Niemniej jednak dla takich koncernów jak Statoil, którego główne złoża na Morzu Północnym stają się coraz droższe w eksploatacji, poszukiwanie nowych źródeł gazu i ropy staje się koniecznością. 
Równocześnie, biorąc pod uwagę obecną sytuację na rynku surowcowym i utrzymujące się na niskim poziomie ceny gazu, rozpoczynanie dużych inwestycji, które wprowadzą kolejne ilości surowca na rynek, niekoniecznie jest rozwiązaniem najbardziej optymalnym.

Otwarte pozostaje również pytanie, czy w Afryce Wschodniej jest miejsce na dwa terminale LNG, gdyż budowa drugiego jest planowana w Mozambiku.

W procesie negocjacyjnym występuje również widoczna asymetria informacji. Reprezentanci korporacji wydobywczych sami przyznawali, że organizują szkolenia dla członków administracji państwowej, podczas których wyjaśniają im, jak działa sektor górnictwa gazu i w jaki sposób należy efektywnie ściągać podatki od korporacji (sic!). Rząd tanzański ma jednak świadomość, że może nie być w stanie ściągać należnych mu danin, jeśli uruchomiona zostanie produkcja gazu, dlatego też w procesie negocjacyjnym bardzo mocno stawia na - wzmiankowaną wcześniej - konieczność wdrożenia efektywnego local content law, tj. konieczności wyboru przez korporacje wydobywcze tanzańskich usługodawców i tanzańskich towarów. Jest jednak tajemnicą poliszynela, że korporacje mogą w taki sposób konstruować warunki zamówienia, iż w Tanzanii nie znajdą się podmioty gospodarcze, które byłyby w stanie spełnić określone w nich warunki (np. ilość towaru lub jego specyfikacja techniczna), co w efekcie może prowadzić do pogłębienia niezadowolenia społecznego i wzmocnienia poczucia bycia wyzyskiwanym przez korporacje gazowe.

Ponadto problemem, na rozwiązanie którego tanzańska administracja wydaje się nie być gotowa, są ceny transferowe w rozliczeniach pomiędzy spółkami matkami i córkami w przemyśle wydobywczym. Jest sytuacją paradoksalną i w dużej mierze patologiczną, że to Statoil przeprowadza szkolenia dla urzędników tanzańskiego urzędu skarbowego (ang. Tanzania Revenue Authority), w jaki sposób mają oni wykrywać i przeciwdziałać cenom transferowym w przemyśle wydobywczym.

Najważniejszym wynikiem badań jest odkrycie nowego i zdefiniowanego według najlepszej wiedzy autorów (prezentowanego wcześniej w dyskursie akademickim) pola w relacjach rząd-koncerny wydobywcze, na którym ogniskuje się proces negocjacyjny - walki o kontrolę nad czasem wdrażania określonych rozwiązań w życie. Korporacje chcą mieć wpływ na przebieg procesu negocjacyjnego przez możliwość odwlekania w czasie decyzji o budowie terminala LNG. Natomiast rząd chce wprowadzać w życie regulacje, które umożliwią mu długookresowe korzyści z górnictwa gazu, mając jednak świadomość, że posiada dużo mniejszą wiedzę techniczną od koncernów wydobywczych. To koncerny 
zdecydują, kiedy i czy w ogóle będą wydobywały gaz w Tanzanii, co daje im możliwość ciągłego wywierania wpływu na administrację państwową. Wpływ ten będzie możliwy tak długo, aż nie powstanie terminal LNG. Wydaje się, że koszt jego budowy będzie tak duży, że po jego powstaniu wydobycie będzie musiało mieć miejsce. Jednakże do momentu zbudowania terminala LNG korporacje posiadają efektywną dźwignię negocjacyjną, która pozwala im domagać się wprowadzania w życie satysfakcjonujących je rozwiązań w danej perspektywie czasowej. Rząd natomiast stworzył zręby ram prawno-instytucjonalnych regulujących proces wydobycia, co - jak zauważono powyżej - jest wyjątkowe w kontekście państw surowcowych w Afryce, gdzie zazwyczaj produkcja określonych kopalin odbywała się równolegle z tworzeniem regulacji w tym zakresie, a nierzadko rozpoczynała się przed ich wejście w życie.

\section{REFLEKSJE KOŃCOWE}

Tanzańskie zasoby gazu nie należą do najatrakcyjniejszych na świecie, jednakże ze względu na ich charakter (złoża typu offshore ${ }^{7}$ ) i położenie relatywnie blisko perspektywicznych rynków azjatyckich mogą być interesującą alternatywą dla gazu pochodzącego z regionu Zatoki Perskiej czy Morza Północnego.

Tanzania jest państwem stabilnym politycznie, które przez dekady charakteryzował neopatrymonialny system rządów. Walka nowej administracji z neopatrymonializmem czyni obecną sytuację wysoce nieprzewidywalną, jednakże to polepszenie bytu Tanzańczyków będzie dla CCM kluczem do wygrania kolejnych wyborów. Według innego scenariusza, dodatkowe wpływy budżetowe z gazu mogą posłużyć do utrzymywania sieci patronażu w CCM. Z formalnego punktu widzenia, wykorzystanie środków pochodzących ze sprzedaży gazu na utrzymywanie patronażu politycznego może być utrudnione, jeśli Tanzania rzeczywiście wprowadzi w życie tzw. norweski model zarządzania sektorem surowcowym, który zakłada oszczędzanie dużej części dochodów pochodzących z górnictwa. Niemniej, przynajmniej na poziomie retorycznym, obecna administracja chce wprowadzać w życie program przekształcenia Tanzanii w kraj o średnim dochodzie i jej priorytetem jest industrializacja oraz akumulacja kapitału wewnątrz Tanzanii. Zwiększenie rocznych dochodów budżetowych o ponad 15\% dzięki

Złoża takie pomimo, iż droższe w eksploatacji są w mniejszej mierze narażone na obstrukcję i protesty lokalnych społeczności związane np. z przesiedleniami, czy tytułami własności. 
eksportowi gazu, znacznie przybliżyłoby Tanzanię do osiągnięcia założonych celów rozwojowych, a co za tym idzie - wygrania kolejnych wyborów przez CCM. Tym samym pozostanie CCM u władzy jest skorelowane z koniecznością podnoszenia dochodów państwa.

Koncerny produkujące gaz są świadome, że obecna administracja państwowa posiada dużo mniejszą wiedzę na temat sektora wydobywczego niż one, rząd natomiast stara się wprowadzać regulacje, które nakazywałyby koncernom wydobywczym w większej mierze opierać się na lokalnych dostawcach towarów i usług, gdyż wie, iż może nie być w stanie efektywnie ściągać należnych mu danin po rozpoczęciu produkcji. Korelacja obecnej sytuacji z produkcją złota i tanzanitu nie dają podstaw do optymizmu w tym zakresie. Niemniej rząd jest świadomy, iż proces negocjacyjny z koncernami wydobywczymi charakteryzuje duża asymetria wiedzy. Zaś jedynym skutecznym narzędziem, które ma w swoich rękach jest przedłużanie wydawania decyzji administracyjnych, które pozwala $\mathrm{mu}$ - w jakiejś mierze - kontrolować przebieg negocjacji.

Równocześnie, Tanzania jest państwem wyjątkowym w kontekście subsaharyjskim, gdyż pomimo braku komercyjnej produkcji gazu funkcjonują tam instytucje i regulacje mające na celu unormowanie tego procesu. Pomimo to, ze względu na konieczność budowy terminala LNG to korporacje wydobywcze są w stanie efektywnie kształtować agendę negocjacji z rządem, gdyż ostateczna decyzja o ich długoterminowym zaangażowaniu w Tanzanii w zasadzie jeszcze nie zapadła. Również odkrycie czterokrotnie większych niż tanzańskie złóż gazu u wybrzeży Mozambiku sprawia, że obydwa państwa mogą być postawione w sytuacji gdy będą zmuszone prowadzić licytację na korzystniejsze warunki dla działalności koncernów wydobywczych.

\section{BibliografiA:}

Aglionby, J. (2017). Acacia Mining 'Strongly' Rejects Accusations of Tanzanian Government. Financial Times. Pobrane z: https://www.ft.com/content/ae2503f0274d-38f8-8aef-d44263c6a015.

Auty R. (2002). Sustaining Development in Mineral Economies: The Resource Curse Thesis. London and New York: Routledge.

CIA, The World Factbook, Tanzania. Pobrane z: https://www.cia.gov/library/publications/the-world-factbook/geos/tz.html.

Coulson A. (2013). Tanzania. A Political Economy, Oxford: Oxford University Press.

Czernichowski K., Kopiński D., Polus A. (2012). Klątwa surowcowa w Afryce? Przypadek Zambii i Botswany. Warszawa: CeDeWu. 
Economic and Social Research Foundation (2009). Petroleum Exploration Study. A Baseline Survey Report. Dar es Salaam: ESRF.

Friedrich-Ebert-Stiftung (2015). Tanzania Oil and Gas Almanac. A Reference Guide Publisher by the Friedrich-Ebert-Stiftung Tanzania and Open Oil. Dar es Salaam: Friedrich-Ebert-Stiftung.

Kassum A.N. (2007), Africa's Winds of Change: Memoirs of an International Tanzanian. London: LB. Tauris.

Ministry of Minerals (October 2013). The National Natural Gas Policy of Tanzania 2013. Dar es Salaam. Pobrane z: https://mem.go.tz/wp-content/uploads/2014/02/ THE_NATIONAL_NATURAL_GAS_POLICY_OF_TANZANIA_-_20131.pdf.

Pedersen R.H., Bofin P. (2015), The Politics of Gas Contract Negotiations in Tanzania: a Review. DIIS Working Paper 03, Danish Institute for International Studies.

Scurfield T., Mihalyi D. (September 2017). Uncertain Potential: Managing Tanzania's Gas Revenues. Natural Resource Governance Institute. Pobrane z: https://resourcegovernance.org/sites/default/files/documents/uncertain-potential-managingtanzania-gas-revenues.pdf.

Statoil. Pobrane z: https://www.statoil.com/en/where-we-are/tanzania.html.

The Citizen. (2017). Second Mineral Report: Govt 'Lost Sh108'r in Unpaid Mining Taxes Over 19 Years'. Pobrane z: http://www.thecitizen.co.tz/News/Govt-lost-Sh108trin-unpaid-mining-taxes-over-19-years-/1840340-3967948-19c7atz/index.html.

The East African. (2017). Mining Firms React to Tanzania's New Laws. Pobrane z: http:// www.theeastafrican.co.ke/news/Mining-firms-react-to-Tanzania-new-laws/2558-4006446-9oxml6z/index.html.

The Economist. (19.10.2017). The Dinosaur of Dodoma. John Magufuli is Bulldozing the Opposition and Wrecking the Economy. "The Economist". Pobrane z: https://www. economist.com/news/middle-east-and-africa/21730424-african-socialism-did-notwork-tanzania-last-time-either-john-magufuli.

The Parliament of Tanzania. (2017a). The Natural Wealth and Resources (Permanent Sovereignty) Act 2017 ("Sovereignty Act").

The Parliament of Tanzania. (2017b). The Natural Wealth and Resources (Revenue and Re-Negotiation of Unconscionable Terms) Act 2017 ("Contract Review Act").

The Parliament of Tanzania. (2017c). The Written Laws (Miscellaneous Amendments) Act 2017 ("Amendments Act").

Woodroffe, N., Genasci, M., Scurfield T. (2016). Tanzania's New Natural Resources Legislation: What Will Change? Pobrane z: https://resourcegovernance.org/analysis-tools/publications/tanzania-new-natural-resources-legislation-what-will-change. 